\title{
Registration of Transfer of Property Rights to Land by Buying and Selling and the Problems
}

\section{Priyo Harsono *)}

*) Work as a Civil Servant at the National Land Agency.

\begin{abstract}
This study aims to determine the practice of registering the transfer of title to land in the Tegal Regency Land Office and the efforts made if the registration of the transfer of land rights is late and the efforts made by land buyers to register the transfer of rights if the sale is carried out under the hands and how the legal protection is carried out. if not registered at the Land Office. The approach method used in this research is sociological juridical with analytical descriptive research specifications, as for complementing the data, non-random sampling is carried out by taking samples and conducting direct interviews (interviews) that are free of charge to parties related to land registration.

The results of the study of the problem in this thesis are that there are still delays in registering the transfer of land ownership by way of selling and buying under hand. Delays in registering the transfer of rights at the Tegal Regency Land Office are still often carried out by the Camat as PPAT officials due to his busyness in the Government, for this it is the obligation of land buyers to complete their deeds by making a statement of delay, a statement of physical ownership and a statement of not being in dispute. As for land buyers are often disadvantaged by carrying out the sale and purchase under hand, because when the deed is to be made, the seller has passed away or where his residence is not known, the solution in order to register the transfer of his rights is to use a court decision which has permanent legal force.

Keywords: Transfer of Rights Registration; Right of ownership; Sale and Purchase of Land
\end{abstract}

\section{Introduction}

In order to realize land for justice and prosperity, land direction and policies are based on 4 (four) principles: ${ }^{1}$

a. Land and land must contribute to welfare and open access to prosperity, especially through access to agrarian sources;

b. Land and Land must contribute to creating justice with regard to control, ownership, use and utilization of land;

c. Land and Land must contribute to creating a sustainable agrarian system and resources towards the creation of a social, national and state system;

d. 4.Land and land must contribute to reducing land disputes and conflicts in creating a harmonious co-existence.

${ }^{1}$ Winoto, Joyo. (2010). Teks Sambutan Kepala BPN RI pada Upacara Peringatan 50 tahun Agraria tanggal 24 September 2010, Center for Law and Public Relations of BPN RI, Jakarta. 
Based on the four principles of land management, the government through the National Land Agency of the Republic of Indonesia has formulated a priority agenda, one of which is: Ensuring the strengthening of people's rights to land which can be seen as a strategy to achieve justice and welfare of the people.

In Indonesia, the land is often the object of dispute and disagreement public. One example of community activities that can lead to conflicts over land, namely, buying and selling land and soil were used as collateral in financial institutions such as banks. Basically the thing that triggered the conflict for land sales in the absence of a clear certificate or even without a certificate. In the region of the Indonesian state owned most of the land that the community has not been certified and is generally found in villages where people are not familiar with the law of the land. In general, the soils there are still a pethuk course. ${ }^{2}$

According to the provisions of land registration as meant in Article 19 paragraph (1) of the UUPA, it is a legal registration (rechtcadaster or legal cadaster). In the context of legal registration, land registration becomes a statutory order to the Government to form a Government Regulation (PP) on land registration, in this case PP Number 10 of 1961, which has subsequently been replaced and enhanced by Government Regulation Number 24 of 1997, Gazette The Republic of Indonesia Year 1997 Number 59 concerning Land Registration, where registration is a determining factor in the state development process.

The sale and purchase of land rights that were not made through PPAT, especially in Tegal Regency, were mostly carried out by people with weak economic conditions and low education levels. The community does not yet understand positive law, because of the influence of customary law which determines that the sale and purchase of land rights is legal if both clear and cash requirements are met. In addition, there is still low public interest in land certification because the community's understanding of certificates as proof of land rights is still lacking, they even think that girik is proof of land rights, even though girik is proof of tax payment and most community members have not understand the provisions of land law, especially regarding land registration.

Although customary law confirms the legality of the sale and purchase of land that is not carried out before the PPAT or often referred to as buying and selling under the hands, buyers clearly experience difficulties in proving that their rights to the land that has been purchased have been certified because there is no land sale and purchase deed made before PPAT. it is difficult for buyers to register their land rights at the Land Office. The Head of the Land Office clearly refuses to record the transfer of his rights based on Article 45 of Government Regulation Number 24 of 1997.

In this study, cases of non-fulfillment of material and formal requirements were found in the registration of the transfer of ownership over land through buying and selling at the Tegal Regency Land Office. The seller and the buyer only carry out

2 Kurniawan, Wahyu Arga., \& Khisni, Akhmad. "Juridical Analysis of the Implementation on Project of National Agrarian Operations (PRONA) In the Regency of Blora", Jurnal Akta Volume 6 Issue 4, December 2019, p. 748 url : $\underline{\text { http://jurnal.unissula.ac.id/index.php/akta/article/view/7593 }}$ 
the sale and purchase under hand with a receipt being made and it is not followed by the making of the sale and purchase deed before the PPAT, so that in its development it is detrimental to the land buyer, the land buyer finds it difficult to write the deed because the land seller is not in place and the address is unknown. In this case, the land sale and purchase is located in the village of Dukuhwringin, Slawi District, Tegal Regency between Suhardi and 12 other people as the buyer and Basirun as the seller. Regarding this problem, it has been suggested to the land buyer to request a verdict from the Slawi District Court in obtaining legal certainty of land ownership. Through the decision of the Slawi District Court of Tegal Regency Number 04 / Pdt 6/2008 dated October 19, 2008, which has permanent legal force, the land buyer can continue registering their land rights at the Tegal Regency Land Office.

The problems in this research are: How is the implementation of registration of the transfer of property rights to land by way of sale and purchase and what efforts are made if the owner of land rights is late in registering their transfer of rights in Tegal Regency, what is the problem, and what is the legal protection for holders of land rights .

\section{Research methods}

The approach method used is the sociological juridical approach. The specification used in this research is descriptive analytical, which is a research method that describes the applicable legal regulations in relation to legal theories and practice of positive law implementation concerning the issues under study. Data collection techniques used in this study include: Observation, Interview (interview) which is free guided. The data obtained in this study were processed and analyzed using qualitative analysis methods.

\section{Research Results and Discussion}

\subsection{Stages of Implementation of Registration of Transfer of Ownership Rights to Land.}

As for the practice of registering the transfer of ownership to land in the Tegal Regency Land Office, according to the provisions of PP. 24 of 1997 in conjunction with PMNA No. 3 of 1997 can be divided into three stages, namely the deed preparation stage, the deed making implementation stage and the post deed making stage (registration to the Land Office) as follows: ${ }^{3}$

a. Preparation for Making Deeds

According to the Circular of the State Minister for Agrarian Affairs / Head of the National Land Agency Number 04-1198 dated April 1, 1999, the aspects of legal action are clearly the responsibility of the PPAT, namely:

- Regarding the truth of the events contained in the deed;

- Regarding the object of legal action, both physical data and juridical data;

- Regarding the identity of the parties who are parties who commit legal acts.

${ }^{3}$ Sukartono, interview, 7 February 2011, Head of the Tegal Regency Land Office. 
Based on the results of interviews with PPAT, the practice of making a deed of transfer of land rights can be explained as mentioned above as follows:

- Submission of Application for Deed by the Parties

- Certificate Examination at the Land Office

b. Making Deeds

The making of the PPAT deed must be witnessed by at least two witnesses who according to the applicable laws and regulations are eligible to act as witnesses in a legal act, who testify, among others, regarding the presence of the parties or their proxies, the existence of the documents shown in the making of deeds, and the parties concerned have carried out the legal act.

PPAT is obliged to read the deed of sale and purchase to the parties concerned (seller and buyer) and provide an explanation of the content and purpose of making the deed and the registration procedure for the transfer of rights.

c. Registration of Transfer of Rights to Land

Registration of the transfer of property rights is carried out by submitting a signed deed accompanied by documents to the Head of the Tegal Regency Land Office, in accordance with the provisions of Article 40 of Government Regulation Number 24 of 1997 in conjunction with Article 103 of the Regulation of the State Minister for Agrarian Affairs / Head of the National Land Agency Number 3 of 1997 "PPAT must submit the PPAT deed and other documents required for registration of the transfer of rights concerned to the Land Office no later than 7 (seven) working days from the signing of the relevant deed ".

Based on these provisions, there are 2 (two) important notes that can be written, namely:

- The obligation to register the transfer of title to land by way of sale and purchase is the Notary Officer / PPAT and the Sub-District Officer as temporary PPAT.

- The period of registration made by PPAT to the Land Office is no later than 7 (seven) working days.

Based on research at the Tegal Regency Land Office, the author has obtained data on applications for registration of transfer of land rights by way of buying and selling which are registered late at the Tegal Regency Land Office. From the existing data, it can be seen that the delay in registration of the transfer of rights (submission of the sale and purchase deed) to the Tegal Regency Land Office is carried out by the Camat as PPAT Officer not by the PPAT Notary because the PPAT Notary directly submits / registers the signed sale and purchase deed to the Land Office, while the camat as a public official has a lot of time spent taking care of the government.

The delay in submitting the deed and its files for registration by the PPAT to the Land Office does not result in the cancellation of the deed concerned and according to the author such provisions are appropriate, due to the negligence of PPAT to register the deed from the PPAT within the time limit determined by law, namely no later than 7 (seven) days after the signing of the deed, it is not appropriate for the interests of the parties to be ignored and it is appropriate for PPAT to be 
sanctioned for negligence, therefore legal consequences for violations as regulated in Article 40 mentioned above, according to the provisions of Article 62 PP Number 24 of 1997 is only imposed on the PPAT concerned, while the consequence or land deed can be registered.

Based on the results of interviews with the Head of the Land Rights and Land Registration Section of the Tegal Regency Land Office ${ }^{4}$ so that the sale and purchase deed made by PPAT can still be registered by the Land Office even though the date of signing the deed is late, the land buyer must attach a statement letter containing:

a. Reasons for the delay, for example:

- The applicant's negligence

- Do not have the money to register

b. The land is physically controlled

c. The land is not in dispute

d. The subjects and objects as stated in the sale and purchase deed do not change

\section{The Problem of Registration of Transfer of Ownership to Land by way of sale and purchase made under hand and the efforts made in the completion of registration of the transfer of rights at the Tegal Regency Land Office}

In registering the transfer of certified land rights through sale and purchase, especially in this case the sale and purchase of certified land is not carried out before the PPAT, while one of the parties, namely the old rights holder / certificate owner (seller) is no longer known the address or has died, and the addresses of his heirs are not known. So the Land Office uses the contents of the District Court's decision which is legally binding as a legal basis for carrying out the registration procedure for the transfer of its rights.

The role of the District Court (PN) decision as the basis for the transfer of land rights through sale and purchase is if the sale and purchase of land is carried out under the hands of certified land (without a land sale and purchase deed before PPAT) and the seller or his heirs have died and / or the address is no longer known The role of PN decisions can be seen from two parties, namely the Land Office and the final right holder (buyer).

In obtaining a description of the problematic registration of the transfer of land rights by way of selling and buying under the hands, the authors conducted research on the decision of the Slawi District Court of Tegal Regency Number: 04 / Pdt.G / 2008 dated 29 October 2008 which has permanent legal force as the basis for the rights holder. Finally, as a land buyer, by means of an underhand sale and purchase to be able to continue the registration of his land rights at the Tegal Regency Land Office, while the land object is located in Dukuh Wringin Village, Slawi District, Tegal Regency.

\footnotetext{
${ }^{4}$ Agus Bangun Raharjo, interview, Head of the Land Rights and Land Registration Section of the Tegal Regency Land Office.
} 
Registration of Transfer of Property Rights to...

(Priyo Harsono)

\section{Legal protection for Land Rights Holders if the sale and purchase of their land is made under hand or with a PPAT Deed not registered at the Tegal Regency Land Office}

Currently, many of the people in general are shackled with the issue of land certificates which should be able to prove as proof of their property even though physical evidence has been controlled for several years or even decades, so that the community does not have legal certainty about the status of the land they own, due to lack of knowledge. society regarding land law or regulations regarding land.

a. Public opinion that the sale and purchase agreement under the hand and with the PPAT deed is legally strong

The rationale for the people who are not willing to register their transfer of land rights can be stated as follows:

- With the current situation the land owner feels that he has received legal protection because in addition to being recognized by the Government (through receiving PBB payment) it is also a proof of ownership of land rights.

- Feel ashamed / embarrassed when buying and selling is accompanied by a signature of a receipt or sale and purchase letter because it seems that they do not trust others.

- The status of the inherited land should not be changed, it should be left as before, so there is no need to change the name and taboo over the inherited land, let alone share and sell.

- Soil is not an object that has economic value, but tends to have religious magical value.

- There is a very close bond between the owner of the land and the land, so that the transfer of land rights is rare.

b. The sale and purchase of land with a PPAT Deed is considered valid

The land sale and purchase certificate made by the Land Deed Making Official (PPAT) has the following functions: ${ }^{5}$

- To prove, authentically a certain sale and purchase of a certain plot of land has occurred, on a certain day, by certain parties mentioned therein.

- This is a requirement for registration of sales and purchases to the local Land Office.

c. Changing the name of the land owner letter $C$ Desa through an underhand sale is considered a change in the status of land ownership.

Tax imposition is carried out by issuing a taxation letter in the name of the land owner which is known among the people as: tax return, pipil, girik and others. Since tax is imposed on the owner of the land, a tax receipt that functions as an imposition letter and a token of tax payment, among the people is considered and treated as proof of ownership of the land concerned. The imposition and receipt of tax payments by the Government by the people is interpreted as an acknowledgment of the right to pay taxes on the land concerned by the Government.

\footnotetext{
${ }^{5}$ Faqih, interview, Head of the Sub-district as PPAT Temporary in the Warureja District, Tegal Regency.
} 
In connection with the attitudes and assumptions above, people do not feel safe yet, as long as the land tax receipt they have bought has not been replaced by a new one in their name. In line with the provisions, that the tax collection is a strong indication of the status of the land as customary land rights and taxpayers as the owner.

However, the court's tax receipt is also not accepted as proof of land ownership subject to tax, as stated by the Supreme Court Decision dated 10 February 1960 Number: 34 / K / Sip / 1960, that: "The Land Tax Petuk is not an absolute proof, that the disputed rice field belongs to the person whose name is listed in the land tax application, but it is only a sign of who should pay the tax from the field concerned".

The following is evidence of weak legal guarantees for the ultimate right holder / buyer

a. It is unclear about the certainty of the status of the rights registered

It cannot be known with certainty the status of the rights that are registered, for example Ownership Rights, Business Use Rights, Building Use Rights, Use Rights, Management Rights, Mortgage Rights, Ownership Rights for Flats or Waqf Land.

b. Unclear certainty of the subject of rights

It cannot be known with certainty, whether individual rights holders (Indonesian citizens or foreigners domiciled in Indonesia), a group of people collectively, or legal entities (private legal entities or public legal entities).

c. Unclear certainty of the object of rights

It cannot be known with certainty the location of the land, the boundaries of the land, and the size (area) of the land. The location of the land is on which road, sub-district / village, sub-district, district / city and province. Land boundaries include the north, south, east, and west borders on whose land or land.

In addition, the right holders of the Government and future land buyers will not get the benefits.

a. For rights holders

- Does not give a sense of security.

- Unable to clearly know the physical data and juridical data.

- Difficult in implementing the transfer of rights.

- Land prices remain low.

- Difficult to be used as collateral for debt with a mortgage burden.

- Land and building tax (PBB) determination is easily mistaken.

b. For the Government

- Obstructing the realization of an orderly land administration as one of the Land Orderly chess programs.

- Obstruct Government activities related to land under development.

- Tend to increase disputes in the land sector, for example disputes over land boundaries, illegal land occupations.

c. For prospective buyers or creditors

It will be difficult for prospective buyers or potential creditors to obtain clear information regarding the physical data and juridical data of land which will 
become the object of legal action regarding land. The legal protection of buying and selling under these hands is also limited.

\section{Closing}

The conclusion that can be drawn in this research is the registration of the transfer of land ownership by way of sale and purchase through the following stages: Preparation of deeds; Implementation of making deeds; Registration of transfer of rights at the Land Office. The problems with registering the transfer of ownership to land by way of selling and buying under hand are: The practice of buying and selling land under the hands often harms the buyer because at the time the PPAT deed was being made, the land seller had died and the heirs were difficult to find or the seller is still alive but his address is no longer known, making it difficult for the right holder to register the transfer of his right.

After conducting the research, the author would like to provide several suggestions, including: The need for intensive counseling by government officials, especially the Land Office together with electronic media or direct scheduling to villages with the intention of increasing the legal awareness of the community to register the transfer of their rights to the Land Office. , so that the community will get strong legal protection for their land by obtaining a certificate of ownership as proof of ownership of their land rights.

\section{Bibliography}

Abdul Kadir Muhamad, 1992, Bond Law, Citra Aditya Bakti, Bandung.

Arie Sukanti Sumantri, 2003, Conception Underlying the Improvement of Land Law, University of Indonesia, Jakarta.

Boedi Harsono, 2003, Indonesian Agrarian Law, History of the Formation of the LoGA, the Contents and Implementation of the National Land Law, volume 1, Djambat, Jakarta.

Iman Soetiknyo, 1985, UUPA A Bit of History, Director General of Agrarian Affairs, Jakarta.

JW. Muliawan, 2009, Granting of Property Rights for Residential, Cerdas Pustaka, Jakarta.

Kurniawan, Wahyu Arga., \& Khisni, Akhmad "Juridical Analysis of the Implementation on Project of National Agrarian Operations (PRONA) In the Regency of Blora", Jurnal Akta Volume 6 Issue 4, December 2019, p. 748 url : http://jurnal.unissula.ac.id/index.php/akta/article/view/7593

Rony Hanitijo Soemitro, 1985, Law and Society Study, Alumni, Bandung.

R. Setiawan, 1994, Principles of Engagement Law, Bina Cipta, Bandung.

Rustandi Adiwilaga, 1962, Indonesian Agrarian Law, Masa Baru, Jakarta. 
Saleh Adiwinata, 1984, Interest in Civil and Land Law 1, cet.1, Raja Grafindo Persada, Jakarta.

Soerjono Soekanto, 1982, Introduction to Legal Research, cet II, University of Indonesia, Jakarta.

Sudaryo Soimin, 1994, Land Status and Land Acquisition, Sinar Grafika, Jakarta. 